\title{
The Medieval French Alexander, edited by Donald Maddox and Sara Sturm-Maddox
}

\section{G. Matteo Roccati}

\section{(2) OpenEdition}

10 Journals

\section{Édition électronique}

URL : https://journals.openedition.org/studifrancesi/38892

DOI : 10.4000/studifrancesi.38892

ISSN : 2421-5856

Éditeur

Rosenberg \& Sellier

\section{Édition imprimée}

Date de publication : 1 décembre 2004

Pagination : 331

ISSN : 0039-2944

\section{Référence électronique}

G. Matteo Roccati, «The Medieval French Alexander, edited by Donald Maddox and Sara SturmMaddox », Studi Francesi [En ligne], 143 (XLVIII | II) | 2004, mis en ligne le 30 novembre 2015, consulté le 19 mai 2021. URL : http://journals.openedition.org/studifrancesi/38892 ; DOI : https://doi.org/ 10.4000/studifrancesi.38892

Ce document a été généré automatiquement le 19 mai 2021.

\section{(c)}

Studi Francesi è distribuita con Licenza Creative Commons Attribuzione - Non commerciale - Non opere derivate 4.0 Internazionale. 


\title{
The Medieval French Alexander, edited by Donald Maddox and Sara Sturm- Maddox
}

\author{
G. Matteo Roccati
}

\section{RÉFÉRENCE}

The Medieval French Alexander, edited by DONALD MADDOX and SARA STURM-MADDOX, Albany, State University of New York Press («SUNY series in Medieval Studies»), 2002, pp.

XII-294.

1 Le volume est constitué de seize contributions, en grande partie présentées dans une première version lors d'un colloque tenu à l'Université du Massachusetts, Amherst. Chacune est consacrée à un point particulier, l'ensemble formant une approche systématique de la riche matière médiévale relative à Alexandre.

2 L'introduction (par D.M. et S.S.-M.: Alexander the Great in the French Middle Ages, pp. 1-16) et une chronologie des oeuvres consacrées à Alexandre ouvrent le volume. Titres des contributions qui suivent: Michel ZINK, The Prologue to the «Historia de Preliis»: A Pagan Model of Spiritual Struggle (pp. 21-27); Emmanuèle BAUMGARTNER, The Raid on Gaza in Alexandre de Paris's Romance (pp. 29-38); Douglas KELLY, Alexander's «Clergie» (pp. 39-55); Catherine GAULLIER-BOUGASSAS, Alexander and Aristotle in the French Alexander Romances (pp. 57-73); François SUARD, Alexander's «Gabs» (pp. 75-87); Rupert T PICKENS, 'Mout est proz e vassaus' / 'Mout es corteis': "Vasselage» and Courtesy in the "Roman d'Alexandre» (pp. 89-109); William W. KIBLER, 'A paine a on bon arbre de malvaise raï': Counsel for Kings in the «Roman d'Alexandre» (pp. 111-125); Stephen D. WHITE, Giving Fiefs and Honor: Largesse, Avarice, and the Problem of «Feudalism» in Alexander's Testament (pp. 127-141); Michelle R. WARREN, Take the World by Prose: Modes of Possession in the «Roman d'Alexandre» (pp. 143-160); Catherine Croizy-Naquet, Alexander and Caesar in the «Faits des Romains» (pp. 161-174); Martin GOSMAN, Alexander the Great as the Icon of Perfection in the Epigones of the 
«Roman d'Alexandre» (1250-1450): The «Utilitas» of the Ideal Prince (pp. 175-191); Renate BLUMENFELD-KOSINSKI, Ekphrasis and Memory in the Fourteenth-Century «Parfait du Paon» (pp. 193-202); Michelle SZKILNIK, Conquering Alexander: «Perceforest» and the Alexandrian Tradition (pp. 203-217); Jane H. M. TAYLOR, Alexander Amoroso: Rethinking Alexander in the «Roman de Perceforest» (pp. 219-234); Laurence HARF-LANCNER, From Alexander to Marco Polo, from Text to Image: The Marvels of India (pp. 235-257); Keith BUSBY, 'Codices manuscriptos nudos tenemus': Alexander and the New Codicology (pp. 259-273; présentation synthétique des caractères de la tradition manuscrite).

3 L'index (des noms, titres et certaines notions) termine le volume. 